\title{
Ser um corpo mais humano: visões de professores de ciências e biologia sobre o ser humano
}

\section{BEING A BODY MORE HUMAN: VISIONS OF SCIENCE TEACHERS AND BIOLOGY ABOUT THE HUMAN BEING}

\author{
Karen Christina de A. B. Ramos ${ }^{1}$; Lana Claudia de S. Fonseca ${ }^{2}$; Tatiana Galieta ${ }^{3}$
}

1 Mestre em Ensino de Ciências, Ambiente e Sociedade, UERJ, São Gonçalo, RJ, Brasil - E-mail: ramos.kcab@gmail.com / ORCID: http://orcid.org/0000-0003-4293-0954

2 Doutora em Educação, Professora Associada da UFRRJ, Seropédica, RJ, Brasil - E-mail: lanaclaudiafonseca@gmail.com / ORCID: http://orcid.org/0000-0002-0423-7975

3 Doutora em Educação Científica e Tecnológica, Professora Associada da UERJ, São Gonçalo, RJ, Brasil - E-mail: tatigalieta@gmail.com/ ORCID: https://orcid.org/0000-0002-3822-1947

Palavras-chave: Ser humano. Corpo humano. Ensino de Ciências e Biologia.

Keywords:

Human Being. Human Body. Science and Biology Teaching.
RESUMO: O privilégio de aspectos biológicos e fisiológicos do Ser Humano tem como consequência o detrimento de seus aspectos sociais, culturais e filosóficos no âmbito do Ensino de Ciências e Biologia. Neste artigo apresentamos uma investigação que buscou identificar as principais visões de professores de Ciências e Biologia sobre Ser Humano e as possíveis origens destas visões. Foram selecionados como sujeitos da pesquisa três professores egressos de um mesmo curso de licenciatura e atuantes em uma rede municipal de educação. Os dados foram coletados por meio de questionários e entrevistas semiestruturadas. Identificamos entre os professores as seguintes visões de Ser Humano: biológica, que se sustenta em conhecimentos prioritariamente oriundos das trajetórias escolar, acadêmica e profissional; cultural (que contempla as dimensões histórica e social), que tem origens em contextos diversos, não necessariamente do ensino formal; e filosófica, que deriva de um contexto sociocultural que transcende a formação escolar e acadêmica. Os resultados desta pesquisa apontam a necessidade de que o ensino sobre Ser Humano seja pensado para além do enfoque biológico do Corpo Humano contemplando as dimensões culturais, sociais, históricas e emocionais que constituem o homem.

ABSTRACT: The privilege of biological and physiological aspects of the Human Being has as a consequence the detriment of its social, cultural and philosophical aspects in the scope of the Science and Biology Teaching. In this article, we present an investigation that sought to identify the main visions of Science and Biology teachers about Human Being and the possible origins of these visions. Three professors from the same undergraduate course and active in a municipal education network were selected as subjects of the study. Data were collected through questionnaires and semi-structured interviews. We identified among the teachers the following visions of Being Human: biological, which is based on knowledge primarily from the academic, academic and professional trajectories; cultural (that contemplates the historical and social dimensions), that has origins in diverse contexts, not necessarily of the formal education; and philosophical, which derives from a sociocultural context that transcends school and academic formation. The results of this research point to the need for Human Being teaching to be thought beyond the biological focus of the Human Body, contemplating the cultural, social, historical and emotional dimensions that make up the human being. 
Ensino, Saúde e Ambiente - V13 (1), pp. 280-309, Abr. 2020

\section{Ser um corpo mais humano: visões de professores de ciências e biologia sobre o ser humano}

\section{BEING A BODY MORE HUMAN: VISIONS OF SCIENCE TEACHERS AND BIOLOGY ABOUT THE HUMAN BEING}

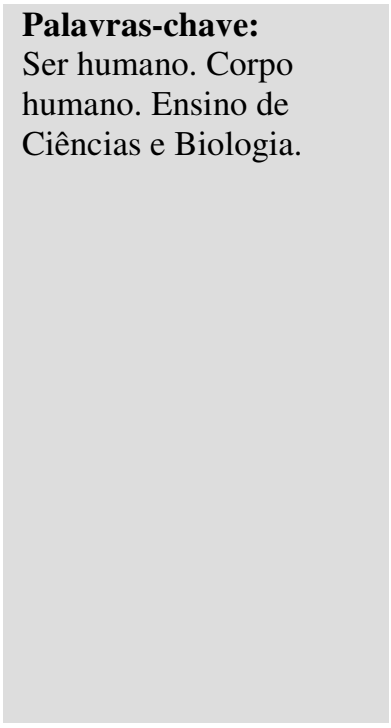

Keywords: Human Being. Human Body. Science and Biology Teaching.
RESUMO: O privilégio de aspectos biológicos e fisiológicos do Ser Humano tem como consequência o detrimento de seus aspectos sociais, culturais e filosóficos no âmbito do Ensino de Ciências e Biologia. Neste artigo apresentamos uma investigação que buscou identificar as principais visões de professores de Ciências e Biologia sobre Ser Humano e as possíveis origens destas visões. Foram selecionados como sujeitos da pesquisa três professores egressos de um mesmo curso de licenciatura e atuantes em uma rede municipal de educação. Os dados foram coletados por meio de questionários e entrevistas semiestruturadas. Identificamos entre os professores as seguintes visões de Ser Humano: biológica, que se sustenta em conhecimentos prioritariamente oriundos das trajetórias escolar, acadêmica e profissional; cultural (que contempla as dimensões histórica e social), que tem origens em contextos diversos, não necessariamente do ensino formal; e filosófica, que deriva de um contexto sociocultural que transcende a formação escolar e acadêmica. Os resultados desta pesquisa apontam a necessidade de que o ensino sobre Ser Humano seja pensado para além do enfoque biológico do Corpo Humano contemplando as dimensões culturais, sociais, históricas e emocionais que constituem o homem.

ABSTRACT: The privilege of biological and physiological aspects of the Human Being has as a consequence the detriment of its social, cultural and philosophical aspects in the scope of the Science and Biology Teaching. In this article, we present an investigation that sought to identify the main visions of Science and Biology teachers about Human Being and the possible origins of these visions. Three professors from the same undergraduate course and active in a municipal education network were selected as subjects of the study. Data were collected through questionnaires and semi-structured interviews. We identified among the teachers the following visions of Being Human: biological, which is based on knowledge primarily from the academic, academic and professional trajectories; cultural (that contemplates the historical and social dimensions), that has origins in diverse contexts, not necessarily of the formal education; and philosophical, which derives from a sociocultural context that transcends school and academic formation. The results of this research point to the need for Human Being teaching to be thought beyond the biological focus of the Human Body, contemplating the cultural, social, historical and emotional dimensions that make up the human being. 


\section{INTRODUÇÃO}

Desde muito pequenos, na escola básica, começamos a entender nosso corpo de maneira fragmentada e com falta de articulação entre as partes, dividido em cabeça, tronco e membros na Educação Infantil, depois dividido entre os sistemas no Ensino Fundamental e mais fragmentado ainda no Ensino Médio quando estudamos, por exemplo, as funções celulares. Os conteúdos são apresentados quase sempre desvinculados ou com grandes lacunas entre as possíveis interações, de modo que os processos vitais parecem totalmente desarticulados.

Logo, percebemos que ao nos referimos ao ensino do Ser Humano nas disciplinas Ciências e Biologia, na maioria das vezes, restringimo-nos aos conteúdos sobre corpo humano. Contudo, quando estudamos sobre o corpo humano não estamos necessariamente estudando a vida, pois o estudo do corpo dissociado de sua interação com outros elementos relaciona-se ao estudo de cadáveres (ou de parte de corpos). Apenas corpos sem vida, que certamente muito nos ensinaram sobre a morfologia e a fisiologia. Algumas perguntas podem surgir, então, derivadas deste enfoque que reduz o ser ao corpo: onde está a dor? O medo? A fome? O amor? Como entender nossas reações, nossos pensamentos, nossa comunicação, que vai muito além da fala e dos movimentos? Somos muito mais do que ossos, massa muscular, órgãos e pele, somos sujeitos pensantes, emotivos, culturais e não apenas um corpo em pedaços.

Apesar de muitos de nós conseguirmos reconhecer todas estas dimensões do Ser Humano, no ensino de Ciências e Biologia a espécie humana é retratada sem sentimentos, pensamentos e emoções, isto é, somos apenas corpos. Reduz-se o conteúdo sobre Ser Humano a Corpo Humano e, assim, desde sempre nos entendemos como corpos, aprendemos somente sobre nossos corpos. No máximo na educação básica encontramos algo sobre os cinco sentidos que observamos no corpo: visão, audição, tato, olfato e paladar. Ou seja, abordamos um corpo isolado e sem conexões com o mundo exterior. É nesse sentido que Shimamoto e Lima (2006), apoiam-se em Merleau-Ponty, para ressaltar que mesmo o corpo não pode ser reconhecido apenas como um conjunto de sentidos.

o corpo é entrelaçamento entre múltiplas dimensões que compõem a estrutura humana e que estão em constante interação consigo próprias, com os outros, com o mundo e, portanto, numa percepção que ultrapassa os limites sensoriais. Ao interagir com o mundo, o corpo recebe e envia estímulos, gerando sensações humanas, e, por 
Ensino, Saúde e Ambiente - V13 (1), pp. 280-309, Abr. 2020

isso, mescladas por múltiplos aspectos. É por isto que, segundo o autor, nós não temos um corpo, nós somos um corpo que expressa o mundo e o mundo se expressa nele, pois toda a relação com o mundo é mediada pelo corpo (SHIMAMOTO e LIMA, 2006, p. 159).

Cassimiro, Galdino e Sá (2012), ainda tendo como foco o corpo, entendem que o homem deve ser compreendido a partir da não dissociação de suas várias dimensões.

Atualmente, existe um vasto acervo bibliográfico que trata do corpo nas várias áreas do conhecimento. Autores como Carmo Junior (2006), Foucault (1979), Santin (2003), e outros que são citados neste trabalho, possuem significativa relevância no meio acadêmico quando a discussão envolve as problemáticas relacionadas ao corpo. Tais autores concentram seus estudos numa visão global, não apenas em seu aspecto biológico, mas também, na dimensão cultural, histórica e filosófica do corpo. Nesse sentido, torna-se imprescindível entender o homem em sua totalidade indissociável (CASSIMIRO, GALDINO e SÁ, 2012, p. 62).

Apesar de concordarmos com os autores supracitados, bem como de reconhecermos a necessidade da comunhão de saberes e da integração de conhecimentos - tão estranha à comunidade científica -, sabemos que as Ciências levaram ao ápice o dualismo e o mecanicismo (nascidos em Descartes) ${ }^{1}$. No caso específico das Ciências Biológicas, que investigam o fenômeno da vida, dedicam-se - além do estudo dos organismos vivos, seus processos vitais e suas interações com outros organismos e com o ambiente - ao estudo da espécie humana.

Mas o que diferencia os seres humanos das demais espécies? A capacidade de superar desafios ou modificar o meio é feita por vários organismos. A diferença é que nós, seres humanos, unimos o raciocínio à capacidade de julgamento das diversas possibilidades que temos em cada situação e, com o desenvolvimento da linguagem, diferimos nosso pensar de qualquer outro organismo. Maturana (1998) apresenta a linguagem como o que nos diferencia das outras espécies.

Penso que ainda quando o racional nos diferencie dos outros animais, o humano se constitui, quando surge a linguagem na linhagem humana à qual pertencemos, na conservação de um modo particular do viver o entrosamento do emocional com o racional que aparece expressado em nossa habilidade de resolver nossas diferenças emocionais e racionais conversando. (MATURANA, 1998, p. 80).

\footnotetext{
${ }^{1}$ A visão dualista, presente na ideia racionalista de homem, pauta-se na separação do espírito (mente) e do corpo que ocorre para melhor conhecer e dominar o mundo. Já o mecanicismo sustenta-se na ideia de que o corpo humano assemelha-se a uma máquina e que, portanto, suas partes devem ser estudadas de forma fragmentada. 
No entanto, não encontramos na grande área das Ciências Biológicas, estudos que contemplem as interações entre emoção, razão e linguagem enquanto constituinte dos seres humanos. Percebemos que a maioria das subáreas de conhecimento ${ }^{2}$ das Ciências Biológicas estuda, entre outras, a espécie humana, porém o objeto de estudo consiste em alguma parte do Corpo Humano (seja ela microscópica, como anticorpos e genes, ou macroscópicas, como os órgãos). Logo, existe um pressuposto implícito no ato de conhecer o Ser Humano dentro das Ciências Biológicas que diz respeito à ideia de que o estudo do Ser Humano é amplo demais e, portanto, deve ser reduzido ao estudo do organismo vivo que se "materializa" no corpo humano ou em alguma de suas partes. Esta é, portanto, uma questão de fundo epistemológico pois existe uma relação intrínseca entre o objeto de estudo, aquilo que se pretende conhecer e o conhecimento produzido a partir de determinados métodos de investigação.

É importante ressaltar, no entanto, que nem sempre as Ciências Biológicas estiveram reunidas sob um único grande "guarda chuva" e que suas fronteiras eram tão bem demarcadas e seus objetos especificados a ponto de haver tamanha especialização em seus ramos de conhecimento. A Biologia passa a ser reconhecida como Ciência Moderna somente quando a teoria evolutiva torna-se o paradigma capaz de unir as vertentes que estudavam espécies animais e vegetais (Zoologia e Botânica), com uma forte característica de identificação e descrição, e aquelas que já possuíam a experimentação como método principal (Citologia, Fisiologia e Embriologia). Sobre este processo unificador, Selles e Ferreira (2005) fazem a seguinte síntese:

De acordo com Smocovitis (1996: 97), apesar de o termo Biologia ter sido cunhado por Lamarck e Treviranus no início do século XIX, as Ciências Biológicas como uma "ciência autônoma e legítima" só puderam ser defensáveis quando a evolução foi articulada como teoria. Antes disso, os conhecimentos biológicos caracterizavam-se, por um lado, pela descrição das espécies animais e vegetais e, por outro lado, pela tradição experimental dos estudos em Citologia, Embriologia e, especialmente, Fisiologia Humana. As Ciências Biológicas não haviam alcançado no século XIX o que a Física conquistara no século XVIII e isto se devia, principalmente, à sua fragmentação. $\mathrm{O}$ surgimento e o avanço da Genética nas primeiras décadas do século XX - área do conhecimento beneficiada pelo refinamento dos métodos experimentais citológicos e por uma abordagem quantitativa -, aliado à influência do Positivismo Lógico e aos movimentos políticos e artísticos ocorridos no âmbito das duas grandes guerras, promoveram uma ressignificação do darwinismo e, conseqüentemente, ganhou força a ideia de

\footnotetext{
2 Biologia Geral, Genética, Botânica, Zoologia, Ecologia, Morfologia, Fisiologia, Bioquímica, Biofísica, Farmacologia, Imunologia, Microbiologia, Parasitologia e Oceanografia, de acordo com a tabela de áreas de conhecimento listadas pelo CNPq. 
Ensino, Saúde e Ambiente - V13 (1), pp. 280-309, Abr. 2020

unificação das Ciências Biológicas. Para Smocovitis (1996), a síntese evolutiva e então parte de todo esse processo (SELLES e FERREIRA, 2005, p. 53).

Assim, entendemos que a "redução" do enfoque do Ser Humano para o Corpo Humano nas Ciências Biológicas acabou por acontecer devido a questões históricas, epistemológicas e constitutivas de uma recente área de pesquisas que foram reunidas em uma grande área de conhecimento devido ao paradigma evolutivo. Esta restrição do "olhar investigativo" sobre o Corpo Humano nas Ciências Biológicas ${ }^{3}$ certamente influenciou os conteúdos e as abordagens sobre o Ser Humano nas disciplinas escolares Ciências e Biologia. Muito embora reconheçamos que as disciplinas escolares se constituem historicamente e sofrem diversas influências neste processo, também admitimos que a ciência de referência (neste caso as Ciências Biológicas) é decisiva no ensino sobre o Ser/Corpo Humano na educação básica, justamente pelo fato de que sua própria epistemologia (na produção de conhecimentos sobre o Ser Humano) restringiu o objeto de estudo.

Foi em torno do questionamento sobre essa redução do ensino do Ser Humano ao ensino do Corpo Humano que, na dissertação de mestrado da primeira autora (RAMOS, 2017), buscou-se investigar as visões de Ser Humano de professores de Ciências e Biologia e suas relações com as práticas docentes. Neste artigo, relatamos parte da pesquisa que tinha como questão norteadora "Quais visões sobre Ser Humano professores egressos de um mesmo curso de Licenciatura em Ciências Biológicas possuem?”4 . O objetivo relacionado a esta questão específica que almejamos alcançar foi: identificar as visões de Ser Humano enunciadas por professores de Ciências e Biologia, bem como suas possíveis origens. Para tanto, realizamos uma revisão dos trabalhos que têm explorado o tema da pesquisa e que puderam sustentar a análise feita no âmbito desta investigação.

\section{SER HUMANO/CORPO HUMANO NO ENSINO DE CIÊNCIAS}

A partir de estudos desenvolvidos nas duas últimas décadas na área de Educação em Ciências, podemos ter a exata noção do foco sobre o ensino do corpo humano em detrimento do ensino sobre o ser humano. Tais estudos têm explorado o tema a partir de diferentes perspectivas, sendo as principais: análise de livros didáticos; investigações das

\footnotetext{
${ }^{3}$ Podemos dizer que a Ecologia é a subárea das Ciências Biológicas em que o Ser Humano é investigado em sua integralidade, como um organismo e não apenas como um corpo. Porém, é mais especificamente na Ecologia Humana que visa compreender a relação do homem com a natureza em várias vertentes, inclusive algumas delas com interfaces com a Sociologia e a Antropologia, que se pode vislumbrar uma visão menos "reduzida" de Ser Humano.

${ }^{4} \mathrm{O}$ curso em questão é oferecido por uma universidade pública situada no estado do Rio de Janeiro que foi objeto de estudo em trabalho final de graduação (monografia) da primeira autora cujo tema também era o ensino do Ser Humano, porém tendo como foco sua matriz curricular (RAMOS, 2013). 
concepções/representações sobre corpo humano de professores e estudantes; abordagens em sala de aula e ensaios teóricos. Buscamos, na sequência, exemplificar alguns destes trabalhos.

Pesquisas que têm como objeto de estudo o livro didático apresentam importantes reflexões sobre o ensino do ser/corpo humano. Em um dos artigos mais antigos e reconhecidos pela comunidade acadêmica, Vargas e cols. (1988) apesar de ressaltarem a dimensão "humana" já focam no ensino do corpo quando afirmam "porque nos cansamos da nossa formação acrítica, tentamos produzir um trabalho que busque um entendimento, mais inteiro, de um CORPO antes de tudo HUMANO, e não apenas DIDÁTICO” (p. 13, grifos das autoras). A partir da análise de livros didáticos editados na década de 1980, as autoras destacam a percepção de que o corpo humano foi reduzido a uma máquina a partir do uso de analogias sustentadas no modelo mecanicista. Além disso, o corpo é ensinado como se todas as suas partes tivessem funções, um corpo estável, organizado e sem idade. Dentre suas conclusões, destacamos:

O "corpo humano didático" é o resultado do abandono das perguntas complexas, de caráter globalizante, que são justamente as perguntas do aprendiz. É com este corpo didático, composto de tijolos, azulejos, tacos e vigas, que o aluno terá que se identificar, deixando de lado todo um universo que, por ser complexo, não é tratado (VARGAS et al., 1988, p. 18).

O estudo de Rabello (1999) tem o mesmo foco que a supracitada, porém analisa livros didáticos de ciências publicados entre 1985 e 1993 voltados para o primeiro segmento do ensino fundamental. A autora conclui que os diferentes autores apresentam uma homogeneidade de estilo que se pauta em informações curtas e superficiais e na fragmentação do corpo humano. A inserção dos conceitos e o uso de analogias, segundo a autora, "não favorecem a construção de uma visão holística do corpo e as atividades propostas parecem requerer principalmente a capacidade de memorização alunos" (RABELLO, op. cit., p. $67 / 68)$.

Mais recentemente, Gonçalves e Silva (2012) analisaram livros didáticos destinados aos anos finais do segundo segmento do ensino fundamental aprovados pelo Programa Nacional do Livro Didático (PNLD - Ciências) de 2011 buscando observar como o tema/conteúdo corpo humano e sexualidade é apresentado nestes materiais. Corroborando as pesquisas anteriores, as autoras encontram nas coleções analisadas a apresentação dos "conhecimentos científicos através da fragmentação do corpo" (GONÇALVES e SILVA, op. cit., p. 7). As conclusões apontam para "a prevalência de referência aos saberes científicos, com pouco diálogo, no conjunto das coleções, com outras formas de saber" (p. 11). Assim, as autoras ressaltam a necessidade de superação do enfoque biomédico a partir da contemplação 
de aspectos sociais e culturais no ensino de ciências, apesar de algumas obras fazerem "uma tentativa de aproximação do tema corpo humano e sexualidade com a dimensão sociocultural" (idem).

Por reconhecermos que o livro didático é não apenas um recurso didático, mas, sobretudo, um objeto simbólico que materializa discursos oriundos dos campos acadêmicos e das políticas públicas, ressaltamos o fato de que as pesquisas sobre o tema vêm há muito tempo sinalizando que o ensino sobre Ser Humano tem sido reduzido ao ensino do Corpo Humano. Pelo simples fato de não encontrarmos pesquisas que tenham como objeto de estudo o Ser Humano em livros didáticos podemos sinalizar a ênfase que as perspectivas fragmentadas e mecanicistas do corpo humano têm assumido no ensino de Ciências e Biologia.

Já os estudos que investigam concepções/representações sobre corpo humano de professores e estudantes têm apresentado resultados que se aproximam daqueles observados nas pesquisas sobre livros didáticos. Talamoni e Bertolhi Filho (2009) entrevistaram 29 alunos do ensino fundamental da rede municipal de ensino de Bauru, SP, e constaram que suas representações de corpo eram muito semelhantes e incompatíveis com o conhecimento científico.

Dentre essas representações, foi possível atentar para a relação explícita ou implícita que se estabeleceu entre a concepção de corpo e de vida, relação esta que foi reiterada por uma visão cartesiana do corpo que, fazendo do primeiro um instrumento ou suporte necessário ao segundo, deve ser objeto de redobrados cuidados (TALAMONI e BERTOLLI FILHO, 2009, p. 85).

O corpo, na visão desses alunos, é definido por atribuições empiricamente observáveis demonstrando um conhecimento tácito por meio de discursos generalistas que explicitam as relações entre o corpo humano e suas funções. Ademais, a representação do corpo como máquina e o uso de metáforas foram destacadas pelos autores.

Essa visão cartesiana e funcionalista do corpo pareceu reproduzir as representações amplamente divulgadas pela mídia em que o corpo comporta analogias com as máquinas e até mesmo nas representações presentes nos livros didáticos (Bertolli Filho; Talamoni, 2007). A utilização de metáforas também se mostrou recorrente, como nas falas a seguir, que reiteraram a concepção mecânica do corpo: "o corpo é como uma máquina, ele não para... ele serve para manter nossa vida, o nosso dia a dia"; "uma pessoa sem uma perna não é uma pessoa comum, se ela não tiver um aparelho, ela não consegue andar" (TALAMONI e BERTOLLI FILHO, 2009., p. $85)$. 
Em outro estudo mais recente que também investigou as percepções de estudantes sobre o corpo humano, Moraes e Guizzetti (2016) coletaram dados por meio de um questionário que foi respondido por 87 alunos do terceiro ano do ensino médio de três escolas (uma particular e duas públicas) localizadas em Uberlândia, MG. O principal resultado encontrado foi a existência de um maior percentual de percepções que indicam um distanciamento entre corpo didático e corpo biocultural. Estas percepções foram denominadas como "reducionistas", pois "representam uma forma fragmentada e distante de visualização do próprio corpo" (MORAES e GUIZZETTI, 2016, p. 268). A percepção reducionista seria "reforçada pelas instituições escolares, que comumente apresentam professores que seguem a tradicional abordagem cartesiana no processo de ensino, além da utilização de livros didáticos que contribuem para um aprendizado fragmentado do corpo humano" (idem). Em contraposição, estariam as "percepções sistêmicas" de corpo humano que são aquelas "que expressam um encadeamento de ideias manifestando alguma integração entre os diversos órgãos e sistemas do corpo, seu próprio corpo e seu entorno" (MORAES e GUIZZETTI, 2016, p. 259). Como estas percepções foram encontradas em menor número, as autoras reforçam a necessidade de se trabalhar para "além dos muros da escola", as experiências e histórias de vida dos alunos de modo que eles identifiquem relações entre o corpo humano didático e estabeleçam significados enquanto corpo biocultural. Elas concluem:

Acreditamos que o estudo integrado sobre o corpo humano além de proporcionar o conhecimento específico sobre o mesmo, pode auxiliar em uma identificação pessoal com as demais pessoas e com o entorno ambiental por parte do aluno. Esta identificação enquanto corpo biocultural poderia levá-lo a estabelecer relações interpessoais mais saudáveis e contribuir para intervenções mais críticas em seu entorno imediato (MORAES e GUIZZETTI, 2016, p. 268).

Shimamoto e Lima (2006) investigaram as representações sociais de 108 professores de ciências do segundo segmento do ensino fundamental da rede pública de ensino de Uberlândia, MG. Com relação às influências recebidas para a construção das representações sobre o corpo humano as autoras observaram que os professores têm consciência destas influências, o que já consiste em ganho qualitativo sobre a compreensão do trabalho docente. Com relação ao núcleo central das representações e os espaços de ancoragem, constata que:

(...) o processo de objetivação das representações sociais dos professores sobre corpo estrutura-se em um núcleo central, predominantemente constituído por elementos da dimensão biológica do corpo humano. O contexto familiar, a formação acadêmica e a própria prática pedagógica constituem espaços para o processo de ancoragem das representações, porque referenciam a construção de concepções de corpos sagrados, silenciados, silenciosos, fragmentados, despersonalizados, 
Ensino, Saúde e Ambiente - V13 (1), pp. 280-309, Abr. 2020

assexuados, intocáveis, individuais, incolores, perfeitos, submissos, dominantes, dominados, entre outros (SHIMAMOTO e LIMA, op. cit., p. 162).

Com relação à prática pedagógica destes professores, elas destacam a prevalência da "realização de um processo de ensino-aprendizagem essencialmente cognitivo, que prioriza aspectos biológicos do corpo humano" (idem). Além disso, a pesquisa também identificou repercussões dessas representações nas interações professor-aluno, na seleção dos conteúdos e na metodologia utilizado pelo professor. Ou seja, a forma como o professor de ciências constrói sua representação sobre o corpo tem influência direta sobre relações interpessoais e atitudes profissionais.

Ao focar tanto as concepções de professores e estudantes como as abordagens de ensino sobre corpo humano, a revisão de literatura feita por Araujo e cols. (2015) em periódicos nacionais da área de Ciências e nas atas dos Encontros Nacionais de Pesquisa em Educação em Ciências (ENPEC) - no período de 2000 a 2014 - traz resultados relevantes sobre esta temática. Os 22 trabalhos encontrados foram divididos em dois grupos segundo a análise de seus objetos de pesquisa: (1) Análise das concepções de corpo apresentadas por professores, alunos e revistas para o publico jovem e (2) Análise das estratégias educativas voltadas para o ensino do corpo humano. Foram classificados 10 trabalhos no primeiro grupo e 12 no segundo. O levantamento aponta que "a dimensão biológica do corpo humano é a que prevalece na maioria dos trabalhos analisados, tanto na visão de professores e alunos como no planejamento de estratégias educativas" (ARAUJO, RAMOS e GIANNELLA, 2015, p. 7) e ainda constataram uma diferença nas abordagens nos níveis fundamental e médio. Os autores concluem que "embora todos os trabalhos chamem a atenção para a necessária integração entre as concepções biológica e sociocultural, esta ainda é um desafio muito grande para o contexto escolar" (ARAUJO, RAMOS e GIANNELLA, op. cit., p. 7), independente de a dificuldade ser metodológica (estratégia de ensino) ou temática (tipo de conteúdo abordado).

Nesse sentido, o ensaio teórico de Trivelato (2005) reconhece que o corpo humano tem sido apresentado aos alunos de Ciências e Biologia restrito a seus aspectos biológicos, estruturado de maneira fragmentada e descontextualizada, porém busca avançar na discussão sobre o corpo/ser humano que habita as escolas. A autora vai além deste enfoque no corpo, buscando a inter-relação entre estes aspectos, quando argumenta que "o ser humano cabe, no ensino, apenas aos pedaços" e "parece que ao avançarmos na escolaridade, avançamos também na fragmentação desse corpo" (TRIVELATO, 2005, p. 122). No entanto, a autora ressalta que essa fragmentação não é fruto da opção dos professores, mas sim está relacionado 
com o percurso que a Ciência trilhou ao longo dos séculos e que se reflete na redução do Ser Humano ao corpo humano, seguida da fragmentação, presente no currículo escolar.

Os estudos que abordam os currículos das disciplinas escolares Ciências e Biologia (TRIVELATO, 2005, SILVA, 2005; MACEDO, 2005) mostram, portanto, a necessidade de reconhecimento das influências culturais, sociais e ambientais não apenas sobre o corpo, mas, sobretudo, sobre o homem. No entanto, esta transformação curricular está relacionada a uma mudança na produção de conhecimentos sobre o ser/corpo humano pelas Ciências Biológicas. Trivelato (2005), sinalizado por outro lado, que pensar o Ser Humano para além do corpo em aulas de Ciências e Biologia requer uma reorganização curricular e uma mudança de paradigma científico.

A partir dos estudos apresentados acima, notamos que o Ser Humano se torna corpo, caracterizado como um objeto de ensino completamente afastado de seus aspectos emotivos, sociais, e culturais. Além disso, mesmo quando se propõem uma abordagem menos "compartimentada", "dualista" (influenciada pela visão cartesiana de corpo humano) e "mecanicista", buscando uma visão mais "integrada" ou "holística", ainda assim o foco é o Corpo Humano e não o Ser Humano. Ou seja, pleiteia-se a integração entre as partes do corpo humano (células, tecidos, órgãos e sistemas) e destas partes - ou do todo (o organismo) - com o ambiente (considerando-se aqui os aspectos sociais e culturais). Entendemos que isso acontece não somente porque historicamente as ciências de referência - Ciências Biológicas assim se estruturaram a partir da delimitação de seus objetos de estudo, mas também porque o próprio ensino de Ciências e de Biologia tem sido pautado a partir de documentos curriculares nos quais o corpo (e suas partes) é central ${ }^{5}$. Apesar de entendermos que esta é uma via de mão dupla, ou seja, as pesquisas da área influenciam os currículos e vice-versa, reafirmamos a necessidade de mudança de um paradigma consolidado no ensino de Ciências e Biologia. Paradigma este, em que o ensino do Ser Humano limita-se ao ensino sobre partes e mecanismos de funcionamento do Corpo Humano para outro em que o Ser Humano possa ser compreendido para além de sua anatomia e fisiologia indo ao encontro de propostas que integrem o ser humano ao ambiente e que reconheçam este ser vivo como sendo resultado de interações sociais, culturais, históricas e dotado de sentimentos, emoções e juízos de valor. Por outro lado, reconhecemos que a mudança passa obrigatoriamente pela formação (inicial e continuada) de professores e por suas práticas docentes. Com base neste reconhecimento delineamos a presente pesquisa, cuja metodologia é apresentada na próxima seção.

\footnotetext{
${ }^{5}$ Em trabalho anterior (RAMOS; FONSECA e GALIETA, 2018) sinalizamos como os principais documentos curriculares vigentes (Parâmetros Curriculares Nacionais) para a educação básica (ensino fundamental e médio) tratam o ensino do ser/corpo humano. 
Ensino, Saúde e Ambiente - V13 (1), pp. 280-309, Abr. 2020

\section{METODOLOGIA DA PESQUISA}

Ao reconhecermos que este estudo pertence à área de Educação em Ciências, enquanto campo de produção de conhecimentos como uma Ciência Humana Aplicada, estamos também postulando que nosso objeto de investigação é fruto de relações sociais situadas em um contexto específico, a saber: o ensino de ciências no âmbito da educação escolar (DELIZOICOV NETO, 2004). A pesquisa que desenvolvemos é, portanto, essencialmente social, uma vez que, "utilizando a metodologia científica, permite a obtenção de novos conhecimentos no campo da realidade social" (GIL, 1999, p.42).

A abordagem de análise dos dados que optamos por desenvolver é qualitativa (MINAYO, 1994). Isto significa que "além da influência de valores no processo de pesquisa, há de se constatar um envolvimento emocional do pesquisador com o seu tema de investigação. A aceitação de tal envolvimento caracterizaria a pesquisa qualitativa" (GÜNTHER, 2006, p. 203). Desta forma, ao delimitarmos o objetivo da pesquisa dentro do tema escolhido reconhecemos o interesse e as motivações intrínsecas que mobilizam e, certamente, interferem no olhar sobre os dados coletados e os movimentos de análise realizados.

Procuramos compreender a visão de ser humano de professores de Ciências e Biologia "segundo a perspectiva dos sujeitos, ou seja, dos participantes da situação em estudo" (GODOY, 1995, p. 58). Na argumentação de Godoy (1995), a autora afirma que "do ponto de vista metodológico, a melhor maneira para se captar a realidade é aquela que possibilita ao pesquisador 'colocar-se no papel do outro', vendo o mundo pela visão dos pesquisados" (p. 61). Portanto, buscamos realizar uma análise na qual partimos dos dados coletados e visando compreender como as falas dos sujeitos respondem às questões da pesquisa.

A pesquisa realizada pode ser caracterizada como sendo, além de qualitativa, empírica já que os dados foram coletados em campo (MINAYO, 1994). De acordo com esta autora, "esta etapa combina entrevistas, observações, levantamentos de material documental, bibliográfico, instrucional, etc.” (p. 26). A partir da coleta de dados empíricos, que consistem nas próprias falas dos sujeitos da pesquisa, realizamos uma análise descritiva e interpretativa visto que a "abordagem qualitativa aprofunda-se no mundo dos significados das ações e relações humanas, um lado não perceptível e não captável em equações, médias e estatísticas" (MINAYO, op. cit., p. 22). 
Ensino, Saúde e Ambiente - V13 (1), pp. 280-309, Abr. 2020

Os instrumentos de coleta de dados utilizados na pesquisa foram questionários e entrevistas. Na primeira etapa de coleta foi aplicado um questionário contendo seis perguntas abertas e dissertativas elaboradas de acordo com os objetivos da pesquisa. O questionário, segundo Gil (1999, p. 128), pode ser definido "como a técnica de investigação composta por um número mais ou menos elevado de questões apresentadas por escrito às pessoas, tendo por objetivo o conhecimento de opiniões, crenças, sentimentos, interesses, expectativas, situações vivenciadas etc.”. As perguntas presentes no questionário eram:

1) O que é o ser humano, para você?

2) Quais as características, ao seu ver, podem diferenciar o ser humano de qualquer outro animal?

3) Como você explicaria o ser humano para um aluno do Ensino Fundamental II (segundo segmento)?

4) Cite 5 (cinco) características do ser humano.

5) Em sua opinião qual seria a diferença entre uma concepção simples de ser humano, de uma concepção complexa?

6) Quais aspectos de sua formação inicial (graduação) você considera terem contribuído para a elaboração de suas respostas anteriores?

$\mathrm{Na}$ segunda etapa da coleta de dados, foram realizadas entrevistas com professores visando aprofundar suas visões através de suas falas. Segundo Minayo (1994, p. 57), “a entrevista é o procedimento mais usual no trabalho de campo. Através dela, o pesquisador busca obter informes contidos na fala dos atores sociais".

As entrevistas seguiram um roteiro prévio, mas que permitia a alteração da ordem das questões ou inclusão de outras, caracterizando-se assim como uma entrevista semiestruturada. Este tipo de entrevista tem um caráter aberto, de forma que "o entrevistador permite ao entrevistado falar livremente sobre o assunto, mas, quando este se desvia do tema original, esforça-se para a sua retomada" (GIL, 1999, p. 120). As entrevistas foram realizadas no segundo semestre de 2016 e tiveram duração entre quarenta minutos a uma hora. As perguntas previamente estruturadas da entrevista foram:

1) Na sua visão o que é o ser humano?

2) Você saberia me dizer de onde surgiram os seus conhecimentos sobre o ser humano? 
Ensino, Saúde e Ambiente - V13 (1), pp. 280-309, Abr. 2020

3) Em sua opinião qual seria a melhor forma de apresentar o ser humano nas aulas de ciências?

4) Existe algum tipo de fator institucional que lhe impeça de alcançar a prática almejada?

A partir da coleta de dados empíricos, que consistem nas próprias falas dos sujeitos da pesquisa, realizamos uma análise descritiva e interpretativa visto que a "abordagem qualitativa aprofunda-se no mundo dos significados das ações e relações humanas, um lado não perceptível e não captável em equações, médias e estatísticas” (MINAYO, 1994, p. 22).

Com relação à escolha dos sujeitos da pesquisa, foi delimitado que estes seriam egressos do curso de Licenciatura em Ciências Biológicas de uma universidade pública situada no estado do Rio de Janeiro. Esta escolha deveu-se ao fato de que a primeira autora desenvolveu seu trabalho final de graduação (monografia) uma análise da matriz curricular deste curso tendo como tema o ensino sobre Ser Humano (RAMOS, 2013). Inicialmente, 20 professores foram contatados dentro da própria universidade na qual se formaram e, após terem conhecimento sobre a pesquisa, informaram seus e-mails para o envio dos questionários, junto com o Termo de Consentimento Livre e Esclarecido (os quais foram devidamente assinados e entregues à pesquisadora). Foram, então, constituídos dois grupos de licenciados, dez em cada um dos grupos, sendo que um deles era de recém-licenciados, ou seja, tinham se graduado nos últimos cinco anos e o outro grupo, formado por professores que além de serem licenciados por essa universidade, atualmente fazem parte do quadro de professores desse curso de Ciências Biológicas.

Dos 20 professores, foram obtidas resposta de dez deles, sendo seis do grupo de recém-formados e quatro do grupo de professores da universidade. Daqueles seis licenciados, três tinham sido convocados recentemente pela secretaria municipal de ensino para lecionarem a disciplina Ciências no ensino Fundamental II. Optamos, então, por utilizar este critério para a seleção dos sujeitos da pesquisa, ou seja, três professores do grupo dos recémformados, egressos do mesmo curso de Ciências Biológicas, tendo em vista que esses professores possuem em comum o fato de ambos lecionarem atualmente no mesmo município. Foram estes três professores que foram, posteriormente, entrevistados pela primeira autora.

Neste trabalho, nomeamos os professores sujeitos da pesquisa como José, Maria e João buscando, desta forma, manter o sigilo com relação às suas identidades. A Professora Maria (24 anos) atua há três anos na Escola Municipal Promotor de Justiça Dr. André Luiz 
Ensino, Saúde e Ambiente - V13 (1), pp. 280-309, Abr. 2020

Mattos de Magalhães Peres (IDEB ${ }^{6}$ observado de 4,3 em 2015). O Professor José (26 anos) atua há dois anos na Escola Municipal Panaro Figueira (IDEB observado foi 3,5 em 2015). O Professor João (29 anos) está há três anos na Escola Municipal Gilson Silva (IDEB observado de 3,5 em 2015).

Com relação ao mecanismo de análise dos dados e à construção das categorias de análise partimos do pressuposto de que a pesquisa se constitui em uma relação intrínseca entre a reflexão e a ação. Desta forma, dialogamos com as respostas aos questionários e com as falas dos entrevistados percorrendo que buscasse responder às questões norteadoras da pesquisa. As categorias de análise utilizadas nesta pesquisa foram definidas a posteriori da coleta dos dados uma vez que resultaram de um movimento de pré-análise dos dados. As duas categorias de análises (e as respectivas subcategorias) que exploramos no presente artigo encontram-se descritas a seguir.

1) Visões de Ser Humano:

- Visão biológica: aquela que apresenta um enfoque nos aspectos anatômicos e fisiológicos, nas características dos seres vivos, muitas delas compartilhadas entre os animais. Esta visão estrutura-se em conhecimentos biológicos, oriundos das Ciências.

- Visão cultural, histórica e social: apresenta os aspectos do convívio social, aprendidos através do contato com outros indivíduos de um grupo específico, refletindo parte da realidade social de cada sujeito. Também reúne os conhecimentos que, a partir de uma dimensão histórica, incluem referências a costumes e hábitos adquiridos através do convívio social e cultural.

- Visão filosófica: cabem aqui os aspectos relacionados às reflexões do homem sobre ele mesmo, sobre sua própria existência no Universo.

2) Possíveis origens das visões de Ser Humano:

- Visão oriunda da trajetória escolar: aquela que construímos ao longo de nossa trajetória pelo ensino fundamental e médio;

- Visão oriunda da trajetória acadêmica e profissional: adquirida ao longo da graduação e das etapas de pós-graduação, e também das experiências advindas da própria prática profissional.

- Visão oriunda do contexto sociocultural: cabem aqui os conhecimentos que têm origem na convivência em outros círculos sociais (como a família, amigos), religiosos, políticos e outros.

\footnotetext{
${ }^{6}$ IDEB (Índice de Desenvolvimento da Educação Básica). Fonte: http://ideb.inep.gov.br/. 
Ensino, Saúde e Ambiente - V13 (1), pp. 280-309, Abr. 2020

$\mathrm{Na}$ próxima seção apresentamos os resultados da análise derivada dos dados coletados em ambos os instrumentos de pesquisa (questionário e entrevista) com intuito de atendermos ao objetivo da pesquisa delimitado neste trabalho.

\section{RESULTADOS E DISCUSSÃO}

\section{Visões de Ser Humano}

Nesta categoria buscamos identificar as visões de Ser Humano apresentadas pelos professores entrevistados e que foram classificadas em quatro subcategorias, elaboradas após a leitura das respostas dos questionários e das transcrições das entrevistas. Ressaltamos que mais de uma visão foi apresentada por um mesmo professor, de modo que elas não são excludentes. As visões sobre Ser Humano foram enquadradas nas seguintes subcategorias: visão biológica, visão cultural, visão histórico-social e visão filosófica, detalhadas a seguir.

\section{$\underline{\text { Visão biológica }}$}

A formação em Ciências Biológicas nos imprime uma ideia que muitas vezes é esquecida pelo senso comum: a de que os seres humanos são animais. Este reconhecimento do homem como pertencente ao Reino Animal, mais especificamente à Classe dos Mamíferos, acaba por conferir um perfil acadêmico às respostas dos professores, conforme observado nas falas abaixo:

\footnotetext{
Este se diferencia dos demais seres vivos por seu cérebro altamente desenvolvido, que associado ao corpo ereto e polegar opositor, torna-o capaz de desenvolver utensílios diversos e alterar o meio ambiente. - (Q1 - Maria)

O ser humano para mim é um animal mamífero, fisiologicamente e morfologicamente semelhante a outros mamíferos. - (Q1 - José)

(...) a gente tem um aspecto biológico, aspecto anatômico, então é toda aquela descrição do humano como espécie, biologicamente. - (E1 - José)
}

Tais marcas da formação, resultado do fato de as Ciências Biológicas virem, ao longo dos anos, estudando as características dos diversos grupos de animais, identificando quais são as compartilhadas e quais são específicas entre os grupos. Esta perspectiva evolutiva, unificadora das Ciências Biológicas, está presente nessa visão de ser humano, pode ser encontrada em falas da Professora Maria.

Seu cérebro altamente desenvolvido associado ao seu corpo ereto e polegar opositor, permitindo assim, o manuseio de objetos que possibilitam a alterar o meio ambiente, favorecendo sua sobrevivência na Terra. - (Q2 - Maria) 
Ensino, Saúde e Ambiente - V13 (1), pp. 280-309, Abr. 2020

Única espécie de primata bípede; possuem o cérebro altamente desenvolvido em relação aos demais animais. - (Q4 - Maria)

Esta professora, inclusive, explicita a influência que sua formação inicial teve sobre sua visão de Ser Humano que acaba por ressaltar funções fisiológicas e características anatômicas.

É assim, o ser humano, quando eu penso em ser humano, né, acho por eu ter feito biologia, a gente pensa mais na parte fisiológica do ser humano (...). Se isso fosse perguntado para mim eu diria que nós somos mamíferos, temos glândulas mamárias, cinco dedos, um polegar opositor. - (E1 Maria)

A formação biológica imprime nas visões desses professores uma perspectiva morfofisiológica, contudo a mesma se amplia quando são convidados a aprofundar essa reflexão, como vemos na fala do professor José:

(...) ele [homem] é tanto uma questão biológica, um ser vivo, um mamífero, mas ele também incorpora muito mais fortemente aspectos culturais. - (E1 - José)

Outro aspecto biológico que foi citado por duas vezes pelo professor João, já anteriormente citado pela professora Maria, foi a questão anatômica da grande cefalização:

Possui grande cefalização, polegar opositor. - (Q4 - João)

A grande cefalização de nós humanos (relação entre o tamanho do cérebro e o tamanho do corpo) possibilitou que essas habilidades fossem possíveis, além do mais temos a capacidade de nos locomovermos com postura ereta (bipedalia), liberando as nossas mãos para a utilização de ferramentas. De certa forma, nos possibilitou o desenvolvimento da escrita. - (Q1 - João).

As falas nos revelam as marcas que o paradigma evolutivo, unificador das Ciências Biológicas e da própria disciplina escolar Biologia (SELLES e FERREIRA, 2005) imprime na visão de Ser Humano.

Dentro da visão biológica, encontramos também a questão da observação da anatomia, o incentivo a auto-observação e à reflexão, porém focada no Corpo Humano:

Eu falo assim: olhem para vocês, olha primeiro para você, seu corpo. O quê que você tem? Olhe para o seu colega e tente observar o que você tem de semelhante do seu colega ou que você tem de diferente? - (E1 - João)

(...) porque que você é diferente dele então nesse aspecto, aí eles falam do nariz, da boca, do olho e aí eu falo você pode olhar agora em vez de olhar pro seu colega, você vai pensar no macaco, o que que o macaco tem de semelhante a você? - (E1 - João)

A ênfase dada aos aspectos biológicos, estruturados de maneira fragmentada e descontextualizada, demonstra que depois de disseminada lógica cartesiana, com a divisão do 
Ensino, Saúde e Ambiente - V13 (1), pp. 280-309, Abr. 2020

corpo e da mente, cabendo às Ciências a preocupação apenas com os limites do corpo, o avanço da medicina e o início da especialização científica, o ensino sobre Ser Humano voltouse para os aspectos morfofisiológicos da espécie humana. Pudemos perceber tal ênfase na maioria das falas dos professores, impregnadas de aspectos mecanicistas. Contudo, podemos perceber que são feitas inter-relações com outros aspectos do ser humano que vão ampliando as visões dos professores, como os aspectos culturais.

\section{Visão cultural, histórica e social}

Algumas menções à importância das questões culturais também foram encontradas nas falas dos professores, a partir de referências a costumes e hábitos, que são adquiridos através do convívio social e são fontes para a construção do entendimento sobre o Ser Humano. Citada como característica determinante, a questão cultural aparece por duas vezes nas falas da professora Maria:

Ser humano, para mim, é um animal composto por um conjunto de características fisiológicas, psicológicas, culturais, sociais e espirituais. - (Q1 - Maria)

Possuem habilidade de alterar o meio ambiente; são constituídos por características fisiológicas, psicológicas e anatômicas, além de características sociais, culturais e espirituais (Q4 - Maria).

As falas acima permitem perceber um movimento de ampliação da visão estritamente biológica contemplando a dimensão cultural na constituição do Ser Humano. O mesmo foi encontrado em falas do professor José:

Ele é tanto uma questão biológica, um ser vivo, um mamífero, mas ele também incorpora muito mais fortemente aspectos culturais. - (E1 - José)

Mas, a gente tem também uma questão cultural, o ser humano, por exemplo, é um animal mamífero capaz de alterar drasticamente o ambiente em que ele vive, para o seu conforto, para aproveitar melhor aqueles recursos. - (E1 - José)

As habilidades de nos comunicarmos, transmitirmos conhecimentos, registrarmos nossa história e modificarmos o ambiente são traços culturais registrados nas falas deste professor:

Somos animais que registram sua história, seja em pinturas em cavernas ou em caracteres, e as passamos à geração seguinte. - (Q2 - José)

II - Capacidade de alterar profundamente o ambiente; IV - animal que registra sua história e cultura deixando-a disponível às gerações. (Q4 - José)

O professor João também citou a escrita e o manuseio de ferramentas: 
Ensino, Saúde e Ambiente - V13 (1), pp. 280-309, Abr. 2020

(...) além do mais temos a capacidade de nos locomovermos com postura ereta (bipedalia), liberando as nossas mãos para a utilização de ferramentas. De certa forma, nos possibilitou o desenvolvimento da escrita. - (Q1 - João)

(...) possui um sistema de códigos bem rico, capacidade de registrar o conhecimento - (Q4 - João).

A questão da religião, que é uma característica cultural dos povos foi citada por Maria, que falou também sobre a essência humana:

(...) e hoje não, eu acho que eu penso mais também que o ser humano tem mais essa capacidade, essa habilidade de comunicação, de transformação de situações em palavras, eu acho isso bem interessante no ser humano. (...) E tem a questão religiosa por trás, e tudo mais, porque a gente é bem mais complexo do que só ter glândulas mamárias. - (E1 - Maria)

(...) a essência da pessoa também é meio que baseado nisso, na convivência e no meio social em que estas pessoas vivem, eu acho que isso também interfere. - (E1 - Maria).

Em pesquisa anterior (RAMOS, 2013), ao analisar a temática ser/corpo humano na matriz do Curso de Licenciatura em Ciências Biológicas dos quais os sujeitos são egressos, percebemos que $25 \%$ das disciplinas obrigatórias oferecidas se ocupam de trabalhar uma visão morfofisiológica das espécies animais, em especial a espécie humana e que, aproximadamente, $30 \%$ da matriz apresenta uma visão ampliada que envolve aspectos sociais, culturais, psicológicos da espécie. Ao analisar as falas notamos que há uma inter-relação entre esses aspectos da formação dos professores que, mesmo apresentando uma forte marca biológica, trazem um diálogo com outras dimensões constituintes do Ser Humano.

Recordando-nos que não somos a única espécie a se comunicar e transmitir conhecimentos localizamos a seguinte fala do professor José:

O comportamento e a transmissão de conhecimento a meu, ver, são também semelhantes aos encontrados em outros animais, apenas em grau mais elevado em relação aos outros. - (Q1 José).

Entendemos que as especificidades relacionadas à cultura, apresentadas pelos seres humanos, podem trazer marcas que, se não pensadas cautelosamente, podem entrar na sala de aula colocando o Ser Humano como um ser superior e único capaz de pensar, falar e transformar o mundo. Esta ênfase pode subsumir temáticas sobre outros seres vivos que também desenvolveram linguagens e uma forma complexa de se relacionarem com o meio e abrir caminho para o reforço de uma visão antropocêntrica. Nesse sentido, encontramos uma visão que está em consonância com a Filosofia Antropocêntrica contemporânea, mais especificamente, com linguistas que destacam o papel da linguagem como característica essencial que determina o agir do homem (VAZ, 1998). Além disso, compreendemos que 
Ensino, Saúde e Ambiente - V13 (1), pp. 280-309, Abr. 2020

uma visão de Ser Humano precisa minimizar a ideia de que a transformação do meio torna os seres humanos superiores a outros animais, fato que também pode ser percebido quando os professores falam sobre a linguagem.

Além das características morfológicas que permitiram várias de nossas habilidades, o domínio de técnicas como a escrita, o desenvolvimento de instrumentos, códigos e linguagens determina boa parte das diferenças entre nós e outros animais. - (Q2 - João)

Não que outros animais não compartilhem de algumas habilidades semelhantes, mas nós seres humanos somos animais com grande capacidade de raciocínio, possuímos habilidades para desenvolver instrumentos, nomeamos as coisas, utilizamos códigos e linguagens complexas. - (Q1 - João)

E vem além de todas essas questões físicas, todas as outras coisas, todos os outros adjetivos que a gente encontra em nossa linguagem, isso é algo que o ser humano desenvolveu muito bem, a questão da comunicação - (E1 - João).

A linguagem é apresentada como uma das particularidades de nossa espécie (MATURANA, 1998), ou seja, a capacidade que desenvolvermos através do raciocínio de utilizar códigos e a construção de linguagens complexas (termo utilizado pelo professor João) e, além disso, remete-se ao fato de hoje vivermos em uma estrutura social complexa:

Nós humanos possuímos uma estrutura social complexa, desenvolvemos conhecimentos em várias áreas. Hoje com a velocidade da informação, a acessibilidade do conhecimento, as relações humanas fazem da nossa sociedade uma sociedade tecnológica. - (Q1 - João).

A questão sobre a transformação do meio também foi citada por José e Maria:

Este se diferencia dos demais seres vivos por seu cérebro altamente desenvolvido, que associado ao corpo ereto e polegar opositor, torna-o capaz de desenvolver utensílios diversos e alterar o meio ambiente. - (Q1 - Maria)

Como características exclusivas, cito a capacidade de alterar profundamente ambiente natural, a matéria e a energia, inclusive sintetizando materiais que de outra forma não existiriam. - (Q2 José).

A produção de estruturas e materiais influencia fortemente nossa sociedade e também foi citada por Maria:

Também essa capacidade de construções de coisas e praticidade na hora de resolver coisas, criações de estruturas e materiais que facilitem nossa vida. - (E1 - Maria)

Temos, ainda, uma fala do professor José que ressalta a importância da construção histórico-social na constituição de uma visão de Ser Humano menos fragmentada: 
Ensino, Saúde e Ambiente - V13 (1), pp. 280-309, Abr. 2020

Então para mim o ser humano é um conjunto, ele não é uma resposta só, mas um conjunto de ideias, de coisas, construídas histórica e socialmente. - (E1 - José)

Nesse sentido, Maturana (1997) ajuda-nos a compreender que esta construção histórica e social do Ser Humano está relacionada às constantes interações dentro de uma dimensão individual e coletiva: “(...) os indivíduos em suas interações constituem o social, mas o social é o meio em que esses indivíduos se realizam como indivíduos, (...) não há contradição entre o individual e o social, porque são mutuamente gerativos” (p. 43).

\section{$\underline{\text { Visão filosófica }}$}

Esta categoria enquadra as ideias refletidas nas falas dos professores que caracterizam uma visão filosófica do Ser Humano, entendida como a possibilidade de refletir sobre si mesmo e sobre a existência de forma geral, características estas consideradas exclusivas dos seres humanos pelos sujeitos da pesquisa. As falas do professor José ilustram essa dimensão do Ser Humano:

Em relação a todo o resto da Biosfera, o resto da vida, eu creio que nós sejamos os únicos capazes de refletir, sobre nós, sobre nossa própria existência, sobre o que nós somos, primeiro, que nós existimos, refletir de sua própria presença nesse mundo, nesse planeta. - (E1 - José)

E, principalmente, somos animais que refletem sobre sua própria existência, tanto em relação à Terra quanto ao universo. Somos os únicos animais que alcançaram a noção de que vivemos em um planeta ordinário, que orbita uma estrela também ordinária, em uma galáxia entre bilhões de galáxias ordinárias. - (Q2 - José)

Os professores citam, ainda, características humanas que surgem à medida que somos estimulados a pensar sobre nós mesmos e sobre os outros seres humanos, sejam elas boas ou ruins como, por exemplo: “São egoístas.” (Q4 - Maria); “(...) e sonham.” - (Q4 João). Dentre essas características exclusivas relacionadas à questão existencial, o professor José aponta que apesar de já termos evoluído bastante sobre determinar o futuro podemos, inclusive, prever nosso fim:

III - consciência de sua pequenez no universo; V - animal que tem a capacidade de prever como será o próprio fim, pois terá participação direta nele. (Q4 - José)

A questão existencial está muito bem demarcada na visão filosófica, como podemos observar nas falas dos professores Maria e José, quando abordam a relação que temos com outros seres humanos, para além das relações físicas, e a reflexão sobre a própria existência:

Porque assim, não é só uma questão de você estar ali e ter uma existência. Não é só você ter uma existência física, é mais do que isso. É você agir, interagir, é você pensar, é você colocar suas ideias no mundo, é você discutir essas ideias, ampliar essas ideias, criar opiniões. - (E2 - Maria) 
Ensino, Saúde e Ambiente - V13 (1), pp. 280-309, Abr. 2020

Hoje em dia quando eu penso em ser humano, eu penso como eu sou, relação interpessoal, essas coisas todas têm que ser levadas em consideração, além da estrutura física... - (E1 - Maria)

O ser humano pode ser também o animal que se pergunta sobre a sua própria existência, que se questiona do motivo de ele estar ali, de onde ele veio, e como vai ser o futuro dele em relação a ele mesmo, aos outros seres humanos, e as outras espécies. - (E1 - José)

O professor João nos apresenta parte de sua prática em sala de aula, quando solicita aos alunos para que estes reflitam sobre quem são, introduzindo assim a visão filosófica para eles:

(...) e eu pergunto para eles 'quem é você?', 'quem são vocês?', e eles começam a me dizer as coisas que eles são. E inclusive eu fico me perguntando nesse momento 'o que eu sou também?', 'eu sou um ser humano de fato'. - (E1 - João).

Percebemos que os professores entrelaçam em suas visões sobre Ser Humano dois níveis de compreensão: aquele que diz respeito aos aspectos morfofisiológicos dos seres humanos, que apresentam sua estrutura orgânica e sua dinâmica interna, e um nível relacional, que apresenta uma dinâmica na qual ocorrem as relações com os outros e com o meio, que se materializam por meio de interações sociais (MATURANA, 1997).

\section{Possíveis origens das visões de Ser Humano}

Entender de onde se origina um conhecimento é algo complexo, tratando-se do entendimento sobre a visão de Ser Humano, ainda mais. Essa visão se constrói desde que começamos a nos reconhecer como indivíduos e, independentemente do nível de escolaridade, qualquer indivíduo possui uma ideia sobre ele mesmo e sobre o outro enquanto ser da mesma espécie, visto que a construção desses conhecimentos se inicia a partir de relações interpessoais. A multiplicidade de visões acaba sendo delimitada no decorrer de trajetórias de vida particulares por informações, processos, contatos diversos que vão transformando-as e moldando outras formas de pensar sobre si mesmo e sobre o mundo.

A partir deste entendimento, identificamos nas falas dos sujeitos da pesquisa três possíveis origens dos principais conhecimentos que sustentam as visões de Ser Humano dos professores de Ciências e Biologia.

\section{Visão oriunda da trajetória escolar}

Apesar de já possuirmos o convívio com outros seres humanos desde que nascemos, reconheço a escola como um contexto específico de interação social, onde iniciamos um intenso convívio com outras pessoas de diversas idades e opiniões, começamos a ter a noção de grupo e de interação. Segundo Andretta (2013, p. 94), "a escola constitui-se no lócus privilegiado de um conjunto de atividades que, de forma metódica, continuada e sistemática, 
Ensino, Saúde e Ambiente - V13 (1), pp. 280-309, Abr. 2020

responde pela formação inicial da pessoa, permitindo lhe posicionar-se frente ao mundo". Muitos dos conhecimentos e valores adquiridos na vida escolar são a base para a construção de diversas ideias e comportamentos. A professora Maria reconhece, por exemplo, que sua forma de pensar e conceber o Ser Humano são um reflexo de sua formação escolar, especificamente quando há uma ênfase nos aspectos morfofisiológicos.

A primeira parte que eu falei antes como eu pensava, numa parte mais fisiológica, mais taxonômica, vamos dizer assim, eu adquiri muito dentro da própria escola. O como que é? O que compõem...? - (E2 - Maria)

Este processo formativo inicia-se ainda na educação infantil. O professor José destaca este ponto e ainda relata a influência da religião sobre sua visão de Ser Humano.

(...) veio tanto da escola né, idade escolar, e foi uma mistura de informações. Porque, por exemplo, eu lembro da minha professora do primário e ela era muito religiosa, então eu tinha esse contato tanto com a visão cientifica, que eu sempre tive acesso a livros, quanto a uma visão também religiosa então, esse meu primeiro conhecimento de onde veio o ser humano está entrelaçado, eu não via um conflito inicialmente. - (E2 - José)

Uma característica do período escolar mencionada foi a utilização de livros didáticos na educação escolar, fato citado pelo professor João, que relata sua preferência pela disciplina Ciências atrelando-a a leitura de textos sobre o corpo humano.

Assim na questão de estudar, eu estudava bem mais Ciências do que as outras coisas, tanto que hoje eu me tornei um professor de Ciências. E eu tinha uma relação com os livros de ciências que eu acho que eu perdi um pouco, que era muito forte quando eu estudava, eu ficava lendo muito sobre as nossas coisas, sabe? Sobre nós, como era o nosso corpo. - (E2 - João)

Conforme exposto na revisão de literatura anterior, pesquisas da área de Educação em Ciências cujo foco é o ser/corpo humano no livro didático têm sinalizado que o ensino sobre o Ser Humano tem sido reduzido ao ensino do corpo humano, enfatizando as partes deste corpo e o funcionamento de estruturas (VARGAS et al., 1988; RABELLO, 1999; GONÇALVES e SILVA, 2012). Com base nas falas dos sujeitos da pesquisa é possível notar que a elaboração de uma visão de Ser Humano alinhada aos aspectos biológicos do corpo, sustentada principalmente em sua fragmentação e mecanização, inicia-se ainda na vida escolar do professor de Ciências e Biologia e acaba por se consolidar durante o curso de graduação em Ciências Biológicas.

\section{$\underline{\text { Visão oriunda da trajetória acadêmica e profissional }}$}

Entendemos que não são todos os indivíduos que têm trajetória acadêmica, porém como os sujeitos dessa pesquisa são professores e temos como objetivo entender a origem de 
Ensino, Saúde e Ambiente - V13 (1), pp. 280-309, Abr. 2020

seus conhecimentos sobre o Ser Humano, este período da vida dos sujeitos mostrou-se fundamental, tanto para a formação de uma visão científica, quanto para a formação social desses sujeitos, fato este que está presente na fala de Maria:

Os conteúdos desenvolvidos em aulas dentro da graduação contribuíram para o aperfeiçoamento e aprendizagem de características fisiológicas e anatômicas. Para as características sociais, culturais e espirituais, o ambiente universitário foi uma escola informal, sendo os corredores, bandejão e ambientes informais salas de aula para esse quesito. Claro que, não apenas a universidade possibilitou essa aprendizagem. (Q6 - Maria)

Sobre as disciplinas acadêmicas temos a fala do professor José, que relata a pouca contribuição das disciplinas de referência biológica e afirma ter obtido um maior suporte da parte pedagógica para sua construção na visão de ser humano:

Mas considero que as disciplinas genericamente chamadas de 'pedagógicas' deram bastantes subsídios para formar em mim essa noção de ser humano que vai além da fisiologia e anatomia. Já as disciplinas do núcleo ‘duro’ da biologia contribuíram pouco. - (Q6 - José)

Esta indicação feita pelo professor José foi uma das conclusões de pesquisa anterior, ao perceber que a matriz curricular da Licenciatura apresentava um núcleo de disciplinas biológicas pouco integrado e que era nas disciplinas do núcleo pedagógico que os estudantes eram estimulados a construir uma visão mais ampliada e relacional de Ser Humano (AUTOR 2).

Assumimos, portanto, que "o currículo influencia a formação das pessoas", tornandose "determinante no desenvolvimento do processo de aprendizagem e produção do conhecimento nas dimensões individual, cultural e social" (ANDRETTA, 2013, p. 99). Esta reflexão está presente na fala de João ao relatar os momentos vividos na formação acadêmica que o auxiliaram em sua forma de entender o Ser Humano:

Além de ter sido monitor de biologia humana, acredito que outras discussões sobre questões educacionais, sociais e antropológicas me ajudaram a formar a minha concepção de ser humano. (Q6 - João)

\section{$\underline{\text { Visão oriunda do contexto sociocultural }}$}

As falas representadas nesta subcategoria apontam para outras origens que não sejam o ambiente escolar, acadêmico ou profissional. Encontramos aqui questões sobre o cotidiano e a convivência sociocultural.

E logo depois assim, eu fui mesmo à convivência. Foi adquirido um saber de convívio mesmo né, que a partir da convivência, que você repare mesmo como as pessoas são diferentes, apesar de 
Ensino, Saúde e Ambiente - V13 (1), pp. 280-309, Abr. 2020

terem uma mesma estrutura física, assim, equivalente pelo menos, né. Assim, eu aprendi muito com a convivência com outras classes. - (E2 - Maria).

A professora Maria trata da importância de nos relacionarmos com pessoas de diversas classes sociais, para que possamos ampliar nossa visão sobre ser humano, ressaltando a ideia em outra fala:

Aí eu tenho essa convivência maior com outras pessoas de outros locais com outros pensamentos, acho que ampliou muito minha visão do que é uma pessoa ou como que outras pessoas lidam com a vida de forma geral, porque ser, ser humano é isso, não é? O como que você lida? E não apenas você ser, eu acho que é isso assim. - (E2 - Maria).

A constante mudança e ampliação desse conceito foi trazida também por João, que fala sobre repensarmos sobre nossa visão de Ser Humano todos os dias:

Além de ainda faltar muito para entender, todos os dias repenso o que é ser humano. - (Q6 João).

O dia a dia também está presente em outra fala de Maria:

A bagagem de vida que é acrescida a cada dia, torna-se fundamental para a construção de ideias tão abstratas como o conceito de ser humano. - (Q6 - Maria)

O convívio e o fluxo de informações foram citados pelo professor José, que aponta que sua formação inicial (escola/acadêmica) não contribuiu tanto para a formação de sua visão sobre Ser Humano, inclusive fazendo uma crítica sobre seu estudo fragmentado e reduzido:

Pouco de minha formação inicial contribuiu para essas respostas. Infelizmente o ser humano ainda é muito tratado como objeto de estudo, apenas em suas partes isoladas. (...) O convívio com pessoas de diferentes lugares, pensamentos e origens também ajudou na formação dessa forma de pensar o ser humano que apresentei nas respostas anteriores. (Q6 - José)

Este professor ainda demonstra o entendimento de que o conhecimento sobre o Ser Humano se dá a partir da compreensão do mundo nas relações socioculturais e afirma que:

A própria visão de mundo, o próprio conhecimento sobre o que acontece em torno do mundo, em outros locais, também nos dão informações sobre como são outros seres humanos, apesar de a mesma espécie, mas com vários tipos de atributos diferentes, em relação a cultura, a história de vida, a história do povo, a localização, o contexto geográfico e político do local onde ele mora. (E2 - José)

Com relação ao convívio social a questão do respeito à opinião alheia foi levantada pela professora Maria, que aponta: 
Ensino, Saúde e Ambiente - V13 (1), pp. 280-309, Abr. 2020

A forma como é a troca de experiências, se você aceita ou se você não aceita, porque tem muito disso também, você não precisa mudar a forma como você é, mas você precisa respeitar a opinião do outro, não é? Como você respeitaria a sua. Eu acho isso importante, mas, não é todo mundo que tem isso, daí já é questão da conduta da própria pessoa. - (E2 - Maria)

A partir das falas acima, podemos perceber que as reflexões dos sujeitos da pesquisa quando se remetem a visões de Ser Humano que contemplam as dimensões sociais, culturais, históricas e existenciais estão, geralmente, descoladas da formação escolar e acadêmica. Desta forma, é fundamental atentarmos para os contextos formativos extraescolares que influenciam a elaboração da visão sobre Ser Humano tanto de professores de Ciências e Biologia quanto dos estudantes da educação básica.

\section{CONSIDERAÇÕES FINAIS}

A presente pesquisa teve como objetivo identificar as principais visões de Ser Humano de professores egressos de um mesmo curso de Licenciatura em Ciências Biológicas e as possíveis origens dessas visões. No que diz respeito às visões sobre Ser Humano pudemos perceber que a visão biológica, que tem como base a descrição de características anatômicas e fisiológicas do Ser Humano, associada a um enfoque evolutivo da espécie, foi a mais recorrente nas falas dos três professores sujeitos da pesquisa. Notamos que esta visão sustenta-se em conhecimentos oriundos das trajetórias escolar, acadêmica e profissional. Os anos de escolaridade básica nas disciplinas Ciências e Biologia, cujos currículos e livros didáticos são tradicionalmente focados em conteúdos fragmentados e em uma abordagem mecanicista, são destacados pelos professores. Além disso, a formação inicial também organizada em disciplinas cuja ênfase é o estudo de partes do corpo humano dá continuidade e influencia na construção desta visão biológica. Estes resultados corroboram estudos anteriores da área que ressaltam a restrição do estudo do Ser Humano ao corpo humano. Além disso, é importante não perdermos de vista que este foco está relacionado à própria constituição das Ciências Biológicas enquanto Ciência que reflete na organização das disciplinas escolares e na estrutura dos cursos de graduação.

Por outro lado, também encontramos nas falas dos professores uma visão cultural, histórica e social, aspectos que são dificilmente indissociáveis. O desenvolvimento da linguagem e outras especificidades socioculturais humanas foram citadas pelos professores. Esta visão tem origens em contextos diversos, não necessariamente do ensino formal, porém aponta-se que as disciplinas pedagógicas do curso de licenciatura contribuíram na elaboração desta visão sobre o Ser Humano. 
Menos citada, mas não menos importante, temos a visão filosófica que trata da existência do Ser Humano e de questões sobre a reflexão do homem sobre si mesmo e sobre o universo. Os professores dão pistas de que a reflexão mais ampla sobre o Ser Humano, contemplando perguntas que normalmente nos fazemos sobre nossa origem e nossa morte, não são tradicionalmente abordadas em sala de aula e, portanto, derivam de um contexto sociocultural que transcende a formação escolar e acadêmica.

De uma forma geral, percebemos que tanto a visão biológica (focada em aspectos evolucionistas, como o dedo opositor e o alto grau de cefalização) quanto a visão cultural, histórica e social (focada principalmente na linguagem) e a visão filosófica (capacidade de refletir sobre si mesmo) enfatizam o que é exclusivo do Ser Humano em sua constituição. É sempre destacando no que somos diferentes dos demais animais que os professores definem o Ser Humano. Isto influencia diretamente o ensinar sobre o Ser Humano e, consequentemente, nas visões que os alunos da educação básica terão do Ser Humano, muitas vezes não se reconhecendo como animais já que são tão diferentes e evoluídos. Acreditamos que estas relações interferem na compreensão sobre a Evolução, que é considerada como o eixo integrador das Ciências Biológicas e do ensino de Ciências e Biologia.

Pensamos que os resultados desta pesquisa apontam a necessidade de que o ensino sobre Ser Humano seja pensado, ainda nos cursos de Licenciatura em Ciências Biológicas, para além do enfoque biológico contemplando as dimensões culturais, sociais, históricas e emocionais que constituem o homem. É importante que este enfoque ampliado seja contemplado não apenas nas disciplinas pedagógicas que estão atreladas às Ciências Humanas, mas também nas disciplinas consideradas do "núcleo duro", que estão relacionadas às Ciências Biológicas e Biomédicas. Entendemos que, além disso, seja necessário que os currículos escolares implementem as sugestões que já estão presentes nos documentos curriculares oficiais, sobretudo os Parâmetros Curriculares Nacionais, relativas a um ensino integrado e interdisciplinar do Ser Humano.

Finalmente, destacamos que a presente pesquisa possui algumas limitações principalmente com relação ao número de sujeitos da pesquisa e à restrição do cenário, embora tenhamos efetuado um estudo qualitativo. Portanto, sinalizamos a necessidade de outras investigações empíricas que busquem identificar as visões de Ser Humano de professores de Ciências e Biologia em outros contextos e relacionadas a outros fatores intra e extraescolares. Além disso, consideramos relevante a observação de aulas na educação básica, de modo a refletir sobre como as visões sobre Ser Humano dos professores se concretizam em suas práticas. 
Ensino, Saúde e Ambiente - V13 (1), pp. 280-309, Abr. 2020

\section{REFERÊNCIAS}

ANDRETTA, F. C. Currículo e conhecimento escolar: uma reflexão sobre algumas relações teóricas e práticas. Perspectiva, v. 37, n.140, p. 93-102, 2013. Disponível em:

http://www.uricer.edu.br/site/pdfs/perspectiva/140_376.pdf. Acesso em 26 de fev. 2017.

ARAUJO, C.; RAMOS, P.; GIANNELLA, T. Corpo humano no ensino de ciências: uma revisão da literatura nacional. In: Atas... X Encontro Nacional de Pesquisa em Educação em Ciências. Águas de Lindóia, SP: ABRAPEC, 2015. Disponível em:

http://www.xenpec.com.br/anais2015/resumos/R1358-1.PDF. Acesso em 10 de jul. 2016.

CASSIMIRO, E. S.; GALDINO, F. F. S.; SÁ, G. M. As concepções de corpo construídas ao longo da história ocidental: da Grécia antiga à contemporaneidade. Metávoia, São João Del Rei, MG, n. 14, 2012. Disponível em:

http://www.ufsj.edu.br/portal2repositorio/File/revistalable/4_GERALDO_CONFERIDO.pdf. Acesso em 25 de fev. 2017.

DELIZOICOV NETO, D. Pesquisa em ensino de ciências como ciências humanas aplicadas. Caderno Brasileiro de Ensino de Física, v. 21, n. 2, p. 145-175, 2004. Disponível em: https://periodicos.ufsc.br/index.php/fisica/article/view/6430. Acesso em 26 de fev. 2017.

GIL, A. C. Métodos e técnicas de pesquisa social. 5. ed. São Paulo: Atlas, 1999.

GODOY, A. S. Introdução à pesquisa qualitativa e suas possibilidades. Revista de administração de empresas, v. 35, n. 2, p. 57-63, 1995. Disponível em:

http://www.scielo.br/pdf/rae/v35n2/a08v35n2.pdf. Acesso em 10 de jan. 2018.

GONÇALVES, J. N.; SILVA, E. P. Q. O tema corpo humano e sexualidade no Ensino de Ciências - anos finais do ensino fundamental: em foco o livro didático. In: II Encontro de Iniciação Científica e Tecnológica da UFU. Uberlândia, MG. 2012. Disponível em: http://www.fe.ufg.br/nedesc/cmv/controle/DocumentoControle.php?oper=download\&cod=19 16. Acesso em 10 de jan. 2018.

GÜNTHER, H. Pesquisa Qualitativa Versus Pesquisa Quantitativa: esta é a questão?

Psicologia: Teoria e Pesquisa, v. 22, n. 2, p. 201-210, 2006. Disponível em:

http://www.scielo.br/pdf/\%0D/ptp/v22n2/a10v22n2.pdf. Acesso em 10 de jan. 2018.

MACEDO, E. Esse corpo das Ciências é o meu? In: MARANDINO, M; SELLES, S. E.; FERREIRA, M. S.; AMORIM, A. C. (Orgs.). Ensino de Biologia: conhecimentos e valores em disputa. Niterói: EDUFF, 2005.

MATURANA, R. H. Emoções e linguagem na educação e na política. Belo Horizonte: EDUFMG, 1998.

MINAYO, M. C. S. Pesquisa social: teoria, método e criatividade. Editora Vozes, 1994.

MORAES, V. R. A. de; GUIZZETTI, R. A. Percepções de alunos do terceiro ano do ensino médio sobre o corpo humano. Ciência \& Educação, v. 22, n. 1, p. 253-270, 2016. Disponível em: http://www.scielo.br/pdf/ciedu/v22n1/1516-7313-ciedu-22-01-0253.pdf. Acesso em 10 de jan. 2018.

RAMOS, K. C. de A. Ser um Corpo mais Humano: a visão de professores sobre o Ser Humano no Ensino de Ciências e Biologia. 107f. Dissertação (Mestrado em Ensino de Ciências, Ambiente e Sociedade). São Gonçalo, RJ: PPGEAS/UERJ, 2017. 
. Corpo Humano: o que aprendem os futuros professores de Biologia? Monografia (Licenciatura em Ciências Biológicas). Universidade Federal Rural do Rio de Janeiro. $41 \mathrm{f}$. Seropédica: UFRRJ, 2013.

RAMOS, K. C. A. B.; FONSECA, L. C. S.; GALIETA, T. Visões sobre o ser humano e as práticas docentes no ensino de Ciências e Biologia. Revista Exitus, v. 8, p. 1-22, 2018. Disponível em:

http://www.ufopa.edu.br/portaldeperiodicos/index.php/revistaexitus/article/view/399. Acesso em 21 de nov. 2019.

SELLES, S. E.; FERREIRA, M. S. Disciplina escolar Biologia: entre a retórica unificadora e as questões sociais. In: MARANDINO, M.; FERREIRA, M. S.; AMORIM, A. C.

(Org.). Ensino de Biologia: conhecimentos e valores em disputa. Niterói: EDUFF, 2005.

SHIMAMOTO, D. F.; LIMA, E. F. As representações sociais dos professores de ciências sobre o corpo humano. Revista de Ciências Humanas, n. 39, p. 147-165, 2006. Disponível em: https://periodicos.ufsc.br/index.php/revistacfh/article/view/17990/16940. Acesso em 10 de jan. 2018.

SILVA, E. P. Q. Quando o corpo é uma (des)construção cultural. In: MARANDINO, M; SELLES, S. E.; FERREIRA, M. S.; AMORIM, A. C. (Orgs.). Ensino de Biologia: conhecimentos e valores em disputa. Niterói: EDUFF, 2005.

TALAMONI, A. C. B.; BERTOLLI FILHO, C. Corpo e Educação: as representações de professores do ensino fundamental. Atas do VII Encontro Nacional de Pesquisa em Educação em Ciências. Florianópolis, 2009. Disponível em: http://posgrad.fae.ufmg.br/posgrad/viienpec/pdfs/1076.pdf. Acesso em 10 de jan. 2018.

TRIVELATO, S. L. F. Que corpo/ser humano habita nossas escolas? In: MARANDINO, M; SELLES, S. E.; FERREIRA, M. S.; AMORIM, A. C. (Orgs.). Ensino de Biologia: conhecimentos e valores em disputa. Niterói: EDUFF, 2005.

VARGAS, C. D.; MINTZ, V.; MEYER, M. A. A. O corpo humano no livro didático ou de como o corpo didático deixou de ser humano. Educação em Revista, n. 8, p. 12-18, dez. 1988.

VAZ, H. C. de L. Antropologia Filosófica I. 4. ed. São Paulo: Edições Loyola, 1998.

\section{AGRADECIMENTO}

A CAPES, pela concessão de bolsa de mestrado à primeira autora.

\section{SOBRE OS AUTORES}

\section{KAREN CHRISTINA DE A. B. RAMOS}

Graduada em Ciências Biológicas, Licenciatura Plena, pela Universidade Federal Rural do Rio de Janeiro, Mestre em Ensino de Ciências, Ambiente e Sociedade pela Universidade do Estado do Rio de Janeiro.

\section{LANA CLAUDIA DE S. FONSECA}

Graduada em Ciências Biológicas, Licenciatura Plena, pela Universidade Federal Rural do Rio de Janeiro, Mestre em Educação pela Universidade Federal Fluminense e Doutora em Educação pela 
Universidade Federal Fluminense. É professora Associado III da Universidade Federal Rural do Rio de Janeiro.

\section{TATIANA GALIETA}

Graduada em Ciências Biológicas Licenciatura e Bacharelado em Genética pela Universidade Federal do Rio de Janeiro, Mestre em Educação em Ciências e Saúde pela UFRJ e Doutora em Educação Científica e Tecnológica pela Universidade Federal de Santa Catarina. Professora Associada da Universidade do Estado do Rio de Janeiro. 